\title{
Quercetin-biapigenin nanoparticles are effective to penetrate the blood-brain barrier
}

\author{
Ana Isabel Oliveira ${ }^{1}$ (1) $\cdot$ Cláudia Pinho $^{1} \cdot$ Bruno Sarmento $^{2,3,4} \cdot$ Alberto C. P. Dias $^{5}$
}

Accepted: 18 January 2021

(c) Controlled Release Society 2021

\begin{abstract}
Search for efficient therapeutic agents for central nervous system (CNS) disorders has been extensive. Nevertheless, bloodbrain barrier (BBB) is an obstacle that prevents the majority of compounds to act in these diseases. It is, thus, of extreme relevance the $\mathrm{BBB}$ overcome, in order to deliver a drugs therapeutically active concentration to the action site, with the least losses and interaction with other organs, tissues, or cells. The present study aimed to investigate the potential protective effect of quercetin-biapigenin encapsulated into poly( $\varepsilon$-polycaprolactone) (PCL) nanoparticles against $t$-BOOH-induced oxidative stress in several brain cell lines, as well as evaluate the permeability of those active molecules through an in vitro BBB model. The three cell lines under study (BV-2, hcmec/D3, and U87) presented different reactions to $t$-BOOH. In general, quercetin-biapigenin PCL-loaded nanoparticles were able to minimize compound toxicity they convey, regardless the cell line. Quercetin-biapigenin PCL-loaded nanoparticles (Papp of approximately $80 \times 10-6 \mathrm{~cm} / \mathrm{s}$ ) revealed to be more permeable than free compounds (Papp of approximately $50 \times 10-6 \mathrm{~cm} / \mathrm{s}$ ). As of our knowledge, this is the first report of quercetin-biapigenin PCL-loaded nanoparticle activity in brain cells. It is also the first determining its permeability through $\mathrm{BBB}$, as an effective nanocarrier for brain delivery
\end{abstract}

Keywords Quercetin $\cdot$ Biapigenin $\cdot$ Poly $(\varepsilon$-polycaprolactone $) \cdot$ Nanoparticles $\cdot$ Neuroprotection $\cdot$ Permeability

\section{Introduction}

One of the main debilitating diseases of the twenty-first century is neurodegenerative disorder. Its rapid increase over the last decades is related with the increase of life

Ana Isabel Oliveira

aio@ess.ipp.pt; aio@estsp.ipp.pt

1 Centro de Investigação Em Saúde E Ambiente (CISA), Escola Superior de Saúde -Politécnico do Porto (ESS-P. Porto), 4000-072 Porto, Portugal

2 i3S - Instituto de Investigação E Inovação Em Saúde, Universidade Do Porto, Rua Alfredo Allen 208, 4200-135 Porto, Portugal

3 INEB - Instituto Nacional de Engenharia Biomédica, Universidade Do Porto, Rua Alfredo Allen 208, 4200-135 Porto, Portugal

4 CESPU, Instituto de Investigação E Formação Avançada Em Ciências E Tecnologias da Saúde, Instituto Universitário de Ciências da Saúde, 4585-116 Gandra, Portugal

5 Centre of Molecular and Environmental Biology (CBMA), Biology Department, Department of Biology, University of Minho, 4710-057 Braga, Portugal expectance, as age is considered the biggest risk factor in most neurodegenerative diseases. Moreover, oxidative stress increases in brain during aging [1,2].

Dependent of anatomical and physiological characteristics, central nervous system (CNS) is known to be especially sensitive to oxidative stress. This is due to several factors, as high $\mathrm{O}_{2}$ consumption-the human brain accounts for a small percentage of the body weight. However, it processes $20 \%$ of basal $\mathrm{O}_{2}$ consumption. The brain also possesses high content of iron and ascorbate, which are directly related to lipid peroxidation and high content of easily peroxidizable unsaturated fatty acids (especially 20:4 and 22:6 fatty acids). Also, the brain does not possess high levels of protective defenses, namely antioxidants $[1,3]$.

The brain possesses its own sources of oxidative stress, namely the excitatory amino acids and neurotransmitters whose metabolism lead to the production of reactive oxygen species (ROS). Other sources are generated by the high and constant use of oxygen by the mitochondria. ROS are also produced by CYP450 electron transport and monoamine oxidase activity [4]. The maintenance of redox environment and cell mitochondrial function are, therefore, essential. This 
can be achieved by avoiding the causes of oxidative stress and increase defenses, through endogenous and exogenous antioxidants [3, 5-7].

The delivery of therapeutic agents for brain diseases is not, however, and generally, very efficient, due to the blood-brain barrier (BBB), a highly specialized endothelial cell system that separates blood from the underlying brain cells. It protects neurons from neurotoxic metabolites and acquired xenobiotics and preserves CNS homeostasis. It is also responsible for the transport of metabolites, precursors, and nutrients from the blood to the brain. The brains' extracellular fluid composition is precisely controlled, and it is independent of the circulating blood composition. This enables for an environment in which the brains' integrative neuronal functions can take place. The brain is therefore considered a physical and biochemical barrier [2, 3, 8-10].

The BBB is composed of different cells, namely endothelial cells, pericytes, astrocytes, microglial cells, and neurons, as well as a several enzymes, receptors, transporters, and efflux pumps. The brain blood vessel endothelial cells are characterized by the presence of fenestrae, a low amount of pinocytosis vesicles and tight continuous circumferential junctions between them, known as zonula occludens. These structures make aqueous paracellular pathways impossible to exist. In addition, tight junctions are also relevant in the maintenance of enzymes and receptor polarity luminal and abluminal membranes, ensuring that its specific functions are preserved. They are considered the responsible for BBB properties $[8,10,11]$.

$\mathrm{BBB}$ represents an obstacle for a large number of drugs, such as antibiotics, antineoplastic agents, and several CNS active drugs. Substances' passive diffusion across the brain is related and dependent on its structural and physical-chemical properties, namely molecular size, charge, hydrogen bonding potential, and lipophilicity. Besides compounds essential for brain homeostasis, such as amino acids, hexoses, neuropeptides, and proteins, transported via specific carriers, only lipophilic molecules smaller than $500 \mathrm{Da}$ are able to cross the BBB [8, 10-12].

Besides that, various drugs that, in theory, are able to cross the BBB do not, due to transport systems present different regions, making it dynamically permeable, unpredictable if lipophilicity and molecular weight of the molecules to be transported are the only characteristics to be considered. P-glycoprotein limits the brain access of a wide range of drugs. In fact, over $98 \%$ of the small molecular weight drugs (less than $500 \mathrm{Da}$ ) are unable to cross the BBB $[10,12]$.

Overcoming the $\mathrm{BBB}$ remains therefore as the biggest challenge in treating most brain disorders through effective arrival and deliver of therapeutic agents to the CNS and specific regions of the brain. Several attempts have been made, such as tight junction osmotic opening, use of vasoactive substances, prodrugs and carrier systems, amino acid carriers, and nanoparticles. The last have been considered as carriers of election $[9,12]$.

Nanoparticles serving as drug carriers play an important role in brain drug delivery. They can be used to maintain drug levels in a therapeutically desirable range and increase half-lives, solubility, and permeability of drugs. They can also be structurally adapted to deliver a variety of drugs, improve delivery efficiency, and reduce side effects by targeted delivery $[8,11]$. For brain delivery, and allied to the administration route, they can achieve targeting ability to the brain due to their steric phenomenon concealing themselves from opsonization event induced by macrophages [9].

Quercetin is a widely studied antioxidant compound, with recognized neuroprotective activity. It has been described to protect against several insults, such as $\mathrm{H}_{2} \mathrm{O}_{2}$ [13-15], lipid hydroperoxide [16], 6-hydroxydopamine (6-OHDA) (c), and tert-butylhydroperoxide ( $t$-BOOH) [17], in PC12 cells [16, 17], primary cultured rat cortical cells [13], rat cerebellar granule neurons [14], and human neuronal SH-SY5Y cells [15]. It has also been described to attenuate amyloid- $\beta_{(1-42)}$-induced cytotoxicity and decreased 4-hydroxinonenal levels [18].

Biapigenin is a sparingly studied compound for its possible neuroprotective activity. It has been however described to affect mitochondrial bioenergetics, decreasing mitochondria's ability to accumulate calcium [19]. It has also been suggested that biapigenin modulates the opening of the mitochondrial permeability transition pore through the modulation of adenosine nucleotide translocator function, contributing for enhanced mitochondrial calcium efflux. In consequence reduction of calcium burden and contribution for neuroprotection against excitotoxicity are performed [20].

The combination of both antioxidants, with different but sinergic mechanisms of action and previously reported antioxidant results in both nonencapsulated $[6,7]$ and encapsulated forms [21] presented itself as essential background for this study.

The present study aimed to investigate the potential protective effect of quercetin-biapigenin and quercetinbiapigenin poly( $\varepsilon$-polycaprolactone) (PCL)-loaded nanoparticles against $t$-BOOH-induced oxidative stress several brain cell lines, as well as evaluate its permeability, through the use of an in vitro BBB model.

\section{Material and methods}

\section{Material}

Roswell Park Memorial Institute (RPMI) 1640 medium, Dulbecco's modified Eagle medium (DMEM), PCL, Pluronic ${ }^{\circledR}$ F-68, antibiotic-antimycotic solution, glutamine, 
trypsin-EDTA solution, 3-(4,5-dimethylthiazol-2-yl)2,5-diphenyltetrazolium bromide (MTT), curcumin, and quercetin were purchased from Sigma-Aldrich (St. Louis, MO, USA). Fetal bovine serum (FBS) was purchased from Biochrom KG (Berlin, Germany). All other reagents were of analytical grade.

\section{Methods}

\section{Synthesis of quercetin-biapigenin PCL nanoparticles}

After the isolation of quercetin and biapigenin from aerial parts of H. Perforatum [21], which, briefly, implicated: the plant biomass maceration with a methanol-water solution $(80: 20, \mathrm{~V} / \mathrm{V})$, for 4 days, in the darkness and at room temperature; its gravity filtration and liquid-liquid extraction with diethyl ether; column chromatography with Sephadex LH-20, concentration of the obtained fraction and its purification through a Polyamide CC6 column; finally the fraction identification was performed by HPLC-DAD as previously described [22]. Quercetin-biapigenin PCLloaded nanoparticles were prepared by nanoprecipitation, as described previously [21]. Briefly, $2.5 \mathrm{mg}$ of PCL were dissolved in $1 \mathrm{ml}$ of acetone and added drop by drop into $10 \mathrm{ml}$ of a Pluronic ${ }^{\circledR}$ F-68 (0.1\%) aqueous solution (without cryoprotective agent), stirred at $550 \mathrm{rpm}$ for $3 \mathrm{~h}$ and centrifuged at $15,000 \mathrm{rpm}$ for $30 \mathrm{~min}$ at $4{ }^{\circ} \mathrm{C}$. After its preparation, nanoparticles were washed with MilliQ water, lyophilized and stored in a moisture-free environment for further use. An optimum proportion of PCL/compounds of 1:0.1 was obtained, as described previously [21], and employed in the assays.

\section{Characterization of quercetin-biapigenin PCL nanoparticles}

Mean particle size, polydispersity index (PI), and zeta potential determinations were performed using a Zetasizer NanoZS (Malvern Instruments, Ltd, UK), as previously described [21].

Regarding association efficiency (AE) determination, nanoparticle suspension was centrifuged, as previously described [21]. After, the supernatant was collected and injected in the HPLC, as previously described [22]. The amount of encapsulated compounds was determined by the following equation:

$\mathrm{AE}(\%)=\frac{\text { Total amount of compounds }- \text { Free compounds in supernatant }}{\text { Total amount of compounds }} \times 100$

Loading capacity (LC) was determined by the difference between the initial amount of compounds used to prepare the nanoparticles and the amount present in the supernatant after centrifugation. Nanoparticle total weight was determined through the lyophilization of a nanoparticle suspension.
LC $(\%)=\frac{\text { Total amount of compounds }- \text { Free compounds in supernatant }}{\text { Total weight of nanoparticles }} \times 100$

Nanoparticle yield was determined taking into account the after lyophilization nanoparticles' final weight and the initial amount of compounds to be encapsulated and polymer used in its preparation.

Yield $(\%)=\frac{\text { Total weight of nanoparticles }}{\text { Total weight of compounds and polymer fed initially }} \times 100$

Each sample was analyzed in triplicate. Results are presented as mean \pm standard deviation.

\section{Cell culture}

Immortalized murine microglial cells (BV-2 cell line) and immortalized human brain capillary endothelial cells (homec/ D3 cell line) were kindly donated by Dr. Annika Höhn (German Institute of Human Nutrition, Germany) and Dr. PO Couraud (INSERM, France), respectively. Immortalized human primary glioblastoma cell line (U87 cell line) was obtained from ATCC. Cell lines were cultured in $25 \mathrm{~cm}^{2}$ flasks with DMEM (BV-2) or RPMI (hcmec/D3 and U87) medium. All cell lines were supplemented with $10 \%$ FBS, $2 \mathrm{~mm}$ L-glutamine, and $1 \%$ antibiotic-antimycotic solution, under an atmosphere of $5 \% \mathrm{CO}_{2}$ at $37{ }^{\circ} \mathrm{C}$. Cells were subcultured once a week using $0.25 \%$ trypsin-EDTA and seeded at a density of $1 \times 10^{6}\left(\mathrm{BV}-2\right.$ and homec/D3) or $0.8 \times 10^{6}$ cells (U87) per ml.

\section{Neuroprotective assays against tert-butyl hydroperoxide-induced toxicity}

Cells were plated in 96-multiwell culture plates at a concentration of $1 \times 10^{5}\left(\mathrm{BV}-2\right.$ and hcmec/D3) or $0.8 \times 10^{5}$ cells (U87) per ml. In order to study $t$-BOOH cytotoxicity, $40 \mathrm{~h}$ after plating, medium was discarded and fresh medium with different concentrations of $t$-BOOH was added. Cellular viability was determined at several time points by the MTT colorimetric assay [23].

To study the compounds and nanoparticle influence in cell viability, $40 \mathrm{~h}$ after plating, several concentrations of compounds or nanoparticle were added (concentration equivalent to $1-100 \mu \mathrm{g} / \mathrm{ml}$ of free compounds), and $24 \mathrm{~h}$ later, metabolic activity of the cells was estimated by the MTT assay. Results were expressed as percentage of cell metabolic activity from the control (cells without any compound). To study the compound ability to protect cells against $t$ - $\mathrm{BOOH}$ induced toxicity, two incubation regimens were used: pre-incubation and co-incubation regimen, as previously described [24], with minor modifications. Briefly, in the pre-incubation regimen, cells were incubated with the free or encapsulated compounds for $4 \mathrm{~h}$, followed by a recovery period of $16 \mathrm{~h}$ with fresh medium, allowing the synthesis of cells' antioxidant defenses. Depending on the cell line, cells 
were incubated with different $t$-BOOH concentrations for several periods of time. BV-2 and homec/D3 cells were both incubated with $0.5 \mathrm{~mm}$ for $1.5 \mathrm{~h}$ and $3.5 \mathrm{~h}$, respectively. U87 cells were incubated with $1 \mathrm{~mm} t$-BOOH for $3.5 \mathrm{~h}$.

In the co-incubation regimen, $\mathrm{BV}-2$ cells were incubated with the compounds or nanoparticles and $0.5 \mathrm{~mm} t \mathrm{BOOH}$ for $1.5 \mathrm{~h}$ and $2.15 \mathrm{~h}$. Similarly, hcmec/D3 and U87 were exposed to 0.5 and $1 \mathrm{~mm}$, respectively, for $3.5 \mathrm{~h}$ and $5 \mathrm{~h}$.

\section{Permeability assay}

Permeability assay with hcmec/D3 cells was performed as previously described [25]. Briefly, $4.6 \times 10^{4}$ cells/ $\mathrm{cm}^{2}$ of hcmec/D3 cells were seeded on the apical side of 12-Transwell $®$ cell culture inserts previously coated with rat tail collagen type I. Cells were cultured for 7 days under an atmosphere of $5 \% \mathrm{CO}_{2}$ at $37{ }^{\circ} \mathrm{C}$. Cell medium was changed in days 2,4 , and 7. Cell monolayer integrity was periodically analyzed through the determination of trans-endothelial electrical resistance (TEER) using an endothelial voltohmmeter (World Precision Instruments, Sarasota, $103 \mathrm{FL}$, USA). The resistance value $\left(\Omega \mathrm{cm}^{2}\right)$ of an empty filter was subtracted from each measurement. Three measurements were taken per filter, and each condition was performed in triplicate. The permeability experiments across the cell monolayers were performed in the apical-tobasolateral direction in PBS, $\mathrm{pH}$ 7.4. At different time (30, 60,90 , and $120 \mathrm{~min}$ ), $100 \mu \mathrm{l}$ samples were taken from the basolateral side of the inserts and the same volume of fresh PBS (ph 7.4) buffer was added to replace the withdrawn volume. Sample concentrations were quantified by HPLC method, as described previously [22]. Apparent permeability (Papp) was calculated using equation:

$\operatorname{Papp}(\mathrm{cm} / \mathrm{s})=\frac{([\mathrm{C}] b \times \mathrm{V} b)}{(\mathrm{Ax}[\mathrm{C}] a \times \mathrm{t})}$

where $[\mathrm{C}] a$ is the apical concentration of the compounds at 0 time; $[\mathrm{C}] b$ is the concentration of the compounds in the basal compartment at the end of the assay; $\mathrm{V} b$ is the volume of the basal compartment; $A$ is the surface area available for transport; and $t$ is the length of the time of the assay.

\section{Statistical analysis}

Data was expressed as mean values \pm standard deviation of three independent experiments. Statistical analysis was performed using GraphPad Prism 5.0® software. On the cell metabolic activity assays, one-way ANOVA was employed with Dunnett's multiple comparison test, when comparing each concentration against a control and unpaired Student's $t$ test when comparing two similar concentrations. On the permeability assay, one-way ANOVA was employed with Tukey's post hoc multiple comparison test. Differences were considered to be significant at a level of $p<0.05$.

\section{Results}

\section{Characterization of quercetin-biapigenin PCL nanoparticles}

With the extraction and isolation procedures and as previously reported [21], a high-purity $H$. perforatum fraction, with quercetin and biapigenin $(1: 1 \mathrm{w} / \mathrm{w})$, was obtained. This fraction already possesses reported antioxidant [7, 21] and neuroprotective [19] activities.

Particle size and its distribution are taken as relevant nanoparticle characteristics, due to its importance in in vivo distribution, toxicity, and targeting ability. They can also influence several features, as drug loading and its release [26].

As Table 1 shows, the mean particle size of quercetinbiapigenin PCL-loaded nanoparticles was of $184.9 \pm 9.1 \mathrm{~nm}$, expected if we consider its synthesis methodology [27]. PI reveals a narrow distribution $(0.11 \pm 0.03)$ [28], with values under 0.4 .

Zeta potential was around $-20 \mathrm{mV}(-20.1 \pm 1.2)$, a good indicative of the nanoparticle stability [29]. Its negative value may be due to PCL characteristics on the nanoparticle surface [30].

$\mathrm{AE}$ and $\mathrm{LC}$ are dependent on the drug solubility in the polymer, subsequently related to, for example, the polymer composition and molecular weight [31]. A high AE was

Table 1 Mean particle size, polydispersity, zeta potential, association efficiency and loading capacity of quercetin-biapigenin poly ( $\mathcal{E}$-caprolactone)-loaded nanoparticles

\begin{tabular}{lllllllll}
\hline $\begin{array}{l}\text { PCL: com- } \\
\text { pounds }\end{array}$ & Size (nm) & $\begin{array}{l}\text { Polydispersity } \\
\text { index }\end{array}$ & $\begin{array}{l}\text { Zeta potential } \\
(\mathrm{mV})\end{array}$ & $\begin{array}{l}\text { Association } \\
\text { efficiency }(\mathrm{Q}) \\
(\%)\end{array}$ & $\begin{array}{l}\text { Association } \\
\text { efficiency }(\mathrm{B}) \\
(\%)\end{array}$ & $\begin{array}{l}\text { Association } \\
\text { efficiency } \\
(\mathrm{Q}+\mathrm{B})(\%)\end{array}$ & $\begin{array}{l}\text { Loading } \\
\text { capacity }(\%)\end{array}$ & $\begin{array}{l}\text { Nanoparticle } \\
\text { yield }(\%)\end{array}$ \\
\hline $1: 0.1$ & $185 \pm 4$ & $0.11 \pm 0.03$ & $-20.1 \pm 1.2$ & $99.3 \pm 0.1$ & $99.9 \pm 0.1$ & $99.7 \pm 0.1$ & $5.3 \pm 0.1$ & $60.2 \pm 1.5$ \\
\hline
\end{tabular}

$n=3$; results are showed as mean \pm standard deviation

$Q$ quercetin, $B$ biapigenin 
obtained $(99.7 \pm 0.1 \%)$. A higher LC was however expected. Taking only into account AE percentage, a LC close to $9 \%$ was estimated. If yield is considered $(60.2 \pm 1.5 \%)$, it can be observed that LC is about $60 \%$ of the one expected for an $\mathrm{AE}$ of almost $100 \%$. Therefore, the presented results are in concordance with each other.

\section{Neuroprotective assays against tert-butyl hydroperoxide-induced toxicity}

In order to select the appropriate concentrations for the cytoprotective assays, non-toxic concentrations were first determined. This ensured that no direct cell damage was caused by the compounds tested.

In BV-2 cells, the compounds tested, encapsulated or not, showed increasing cytotoxicity in a concentration-dependent manner (Fig. 1a). In concentrations higher than $5 \mu \mathrm{g} / \mathrm{ml}$, for both nonencapsulated and encapsulated quercetin and biapigenin $(p<0.05)$, there was significant toxicity. In the higher concentrations tested (50 and $100 \mu \mathrm{g} / \mathrm{ml})$, despite toxic, quercetin-biapigenin PCL-loaded nanoparticles were significantly less toxic than pure compounds $(p<0.05$ and $p<0.001$, respectively).

In homec/D3 cells, quercetin-biapigenin in its free form did not induce a significant increase of the cells metabolic activity (Fig. 1b). Quercetin-biapigenin PCLloaded nanoparticles were significantly more protective than pure compounds in concentrations ranging from 5 to $50 \mu \mathrm{g} / \mathrm{ml}$.

Regarding U87 cells and for the nonencapsulated compounds (except $5 \mu \mathrm{g} / \mathrm{ml}$ ) and the quercetin-biapigenin PCL-loaded nanoparticles, the same absence of growth (in comparison to the control group) was verified (Fig. 1c). The nanoparticles were more protective than quercetinbiapigenin in the intermediate concentrations tested (10, 25 , and $50 \mu \mathrm{g} / \mathrm{ml}$ ) being significantly higher at 25 and $50 \mu \mathrm{g} / \mathrm{ml}\left(* p<0.05\right.$ and ${ }^{*} p<0.01$, respectively).

Empty PCL nanoparticles revealed no significant interference in metabolic activity in concentrations lower than $500 \mu \mathrm{g} / \mathrm{ml}$ (data not shown). Higher concentrations revealed to be toxic to BV-2 cells.

In the homec/D3 and U87 cell lines, there was no significant interference in metabolic activity in all concentrations tested (data not shown).

To access the $t$ - $\mathrm{BOOH}$ concentration and contact time between toxic and compounds that could be used in the cytoprotective assays, the different cell lines response was evaluated. In general, when $t$ - $\mathrm{BOOH}$ was used on the cells, the cell viability decreased in a concentrationdependent manner (data not shown). Contact times that provided viabilities lower than $60 \%$ were selected, in accordance to previous studies [23, 24].
In the preincubation regimen, cells were exposed to the compounds in study and its polymeric nanoparticles, followed by a recovery period with fresh medium before the addition of $t$ - $\mathrm{BOOH}$. This reflected, therefore, the cells' ability to produce endogenous antioxidant defenses, due to its exposure to the compounds in study, facing a toxic insult. A smaller concentration $(0.5 \mu \mathrm{g} / \mathrm{ml})$ was added to the cytoprotective assays to better understand the activity of low compound concentrations.

In BV-2 cell line, quercetin-biapigenin PCL-loaded nanoparticles were significantly more protective than pure compounds in higher concentrations $(25-100 \mu \mathrm{g} /$ ml) (Fig. 2a). Quercetin-biapigenin are significantly more protective at 0.5 and $10 \mu \mathrm{g} / \mathrm{ml}(p<0.05$ and $p<0.001$, respectively).

Quercetin-biapigenin did not evidence significant protection against $t$-BOOH insult in homec/D3 cells (except for 10 and $1 \mu \mathrm{g} / \mathrm{ml}$ ) (Fig. 2b). Quercetin-biapigenin PCLloaded nanoparticles, in the higher concentrations tested, 100 and $50 \mu \mathrm{g} / \mathrm{ml}$ are significantly more protective than quercetin-biapigenin $(p<0.001)$ and significantly protect hcmec/d 3 cells against $t$-BOOH-induced toxicity $(p<0.001)$. Quercetin-biapigenin in its free form in high concentrations $(100$ and $50 \mu \mathrm{g} / \mathrm{ml})$ revealed toxicity $(p<0.001$ and $p<0.01$, respectively, when compared with $t$-BOOH group).

For U87 cell line, quercetin-biapigenin PCL-loaded nanoparticles are more protective than pure compounds in all concentrations tested, being statistically more protective in concentrations of $1-10$ and $100 \mu \mathrm{g} / \mathrm{ml}$ (Fig. 2c). Between 1 and $10 \mu \mathrm{g} / \mathrm{ml}$, they also significantly protect cells against $t$-BOOH-induced toxicity (when comparing with $t$ - $\mathrm{BOOH}$ group).

Incubation of cells with both $t$-BOOH and quercetinbiapigenin and its polymeric nanoparticles (co-incubation) reflects the direct antioxidant effect of the compounds on cell $t$-BOOH-induced toxicity mediators.

Here and in BV-2 cells, the same tendency is perceived in the two incubation times selected. Quercetin-biapigenin PCL-loaded nanoparticles were more protective than pure compounds in higher concentrations. In the intermediate concentrations, the opposite is verified. Therefore, and as in Fig. 3a and b, quercetin-biapigenin PCL-loaded nanoparticles were more protective than pure compounds (50 and $100 \mu \mathrm{g} / \mathrm{ml}$ ) and significantly protected against $t$-BOOH induced toxicity. In the concentrations of 5 and $10 \mu \mathrm{g} /$ $\mathrm{ml}$ quercetin-biapigenin in its free form significantly protected against $t$ - $\mathrm{BOOH}$ induced toxicity, being also more protective than its polymeric nanoparticles.

Interestingly, when increasing the incubation time from 3.5 to $5 \mathrm{~h}$, the protective activity of $0.5 \mu \mathrm{g} / \mathrm{ml}$ quercetinbiapigenin in its free form increased slightly, enough to significantly protect the cells against the prooxidant injury 
Fig. 1 Cytotoxicity of different concentrations of quercetinbiapigenin in its free form, and in PCL-loaded nanoparticles on BV-2 a, hcmec/D3 b, and U87 c cells. Cell proliferation was determined by MTT assay after $24 \mathrm{~h}$. Data is presented as mean \pm SD of three independent experiments. $* p<0.05, * * p$ $<0.01$ and $* * * p<0.001$ when compared with the negative control. \# $p<0.05$, \#\# $p^{<} 0.01$, and \#\#\# $p<0.001$ when comparing two similar concentrations
Quercetin-biapigenin

Quercetin-biapigenin PCL-loaded

a nanoparticles
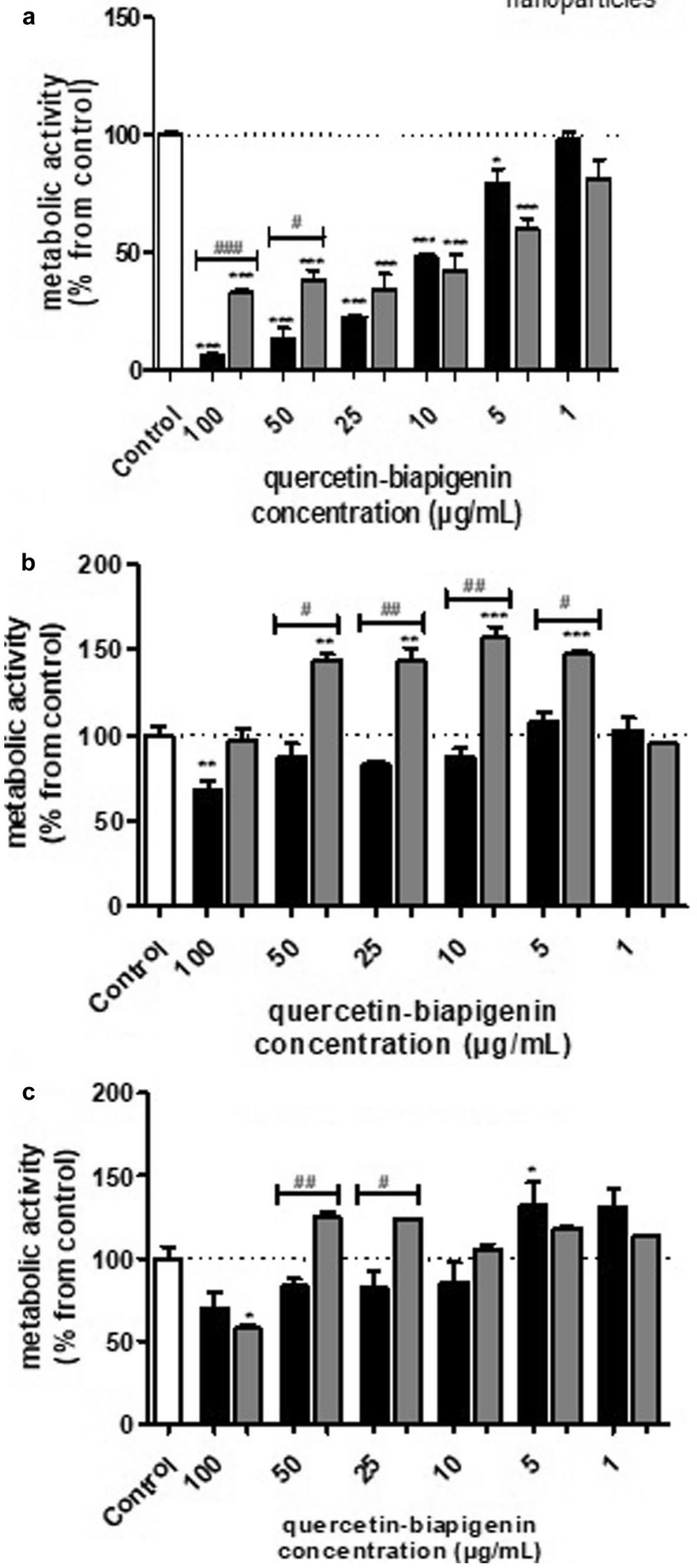
Fig. 2 Cytoprotection of different concentrations of quercetinbiapigenin in its free form, and in PCL-loaded nanoparticles on BV-2 $\mathbf{a}$, hcmec/D3 b, and U87 c cells (pre-incubation regimen). Cells were pretreated with or without compounds for $4 \mathrm{~h}$ and then exposed to $0.5 \mathrm{~mm}$ $t$-BOOH for $1.5 \mathrm{~h}$ (for BV-2 cells) or $3.5 \mathrm{~h}$ (for hcmec/D3 ans U87 cells) and cell proliferation was determined by MTT assay. Curcumin $20 \mu \mathrm{m}$ (Curc) was used as a positive control. Data is presented as mean $\pm \mathrm{SD}$ of three independent experiments. $* p^{<} 0.05$, ** $p^{<} 0.01$, and $* * * p<0.001$ when compared with the $t$-BOOH control. \#p $<0.05, \# \# p<0.01$, and \#\#\#p

$<0.001$ when comparing two similar concentrations
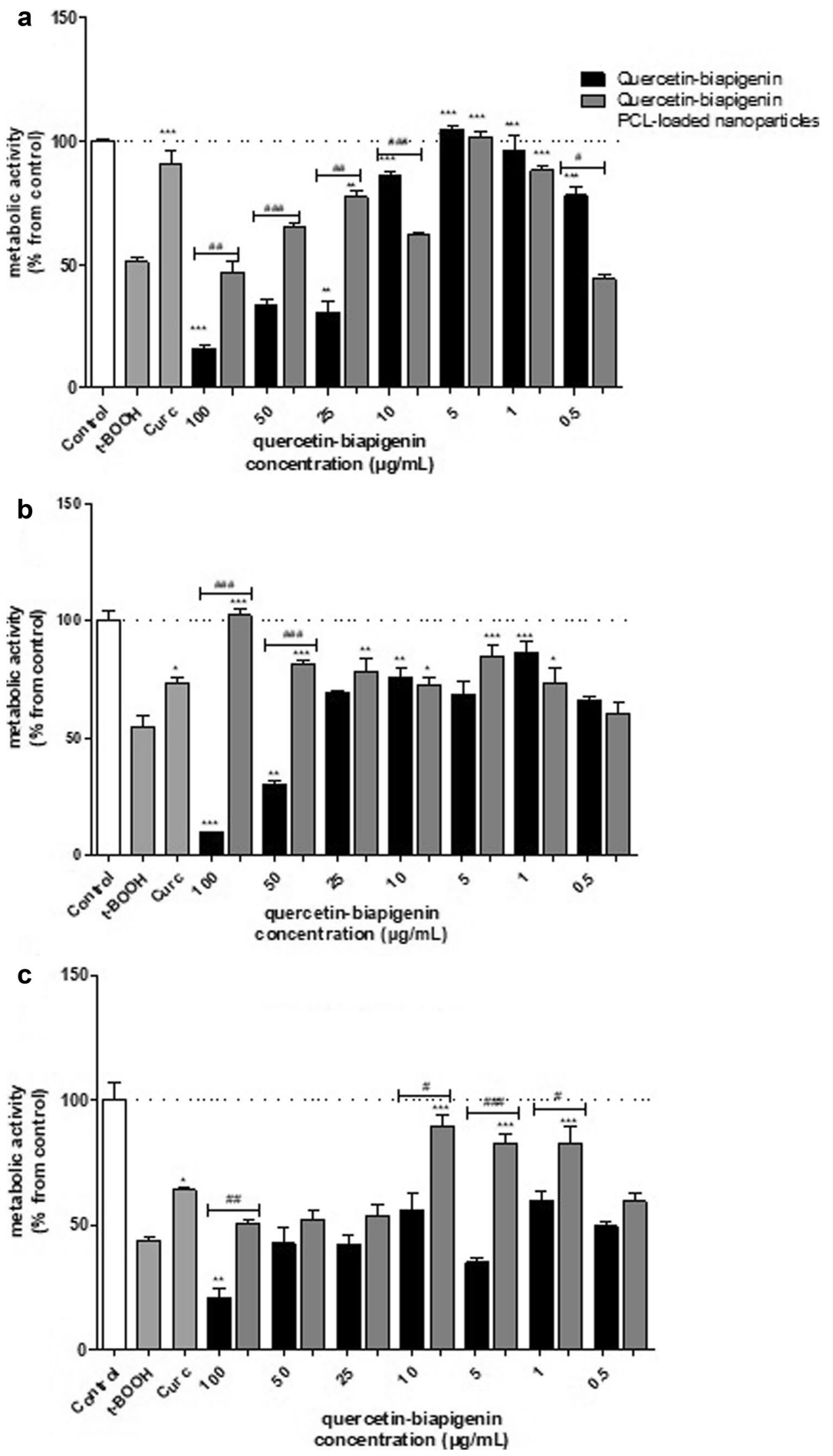
Fig. 3 Cytoprotection of different concentrations of quercetinbiapigenin in its free form, and in PCL-loaded nanoparticles on BV-2 cells ( $1.5 \mathrm{~h}$ a or 2.15 b co-incubation regimen). Cells were treated with or without compounds along with $0.5 \mathrm{~mm}$ $t$-BOOH for $1.5 \mathrm{~h}$, and cell proliferation was determined by MTT assay. Quercetin $10 \mu \mathrm{m}$ (Q) was used as a positive control. Data is presented as mean \pm SD of three independent experiments. ${ }^{*} p<0.05, * * p$ $<0.01$ and $* * * p<0.001$ when compared with the $t$ - $\mathrm{BOOH}$ control. $\# p<0.05$ and \#\#p< 0.01 when comparing two similar concentrations

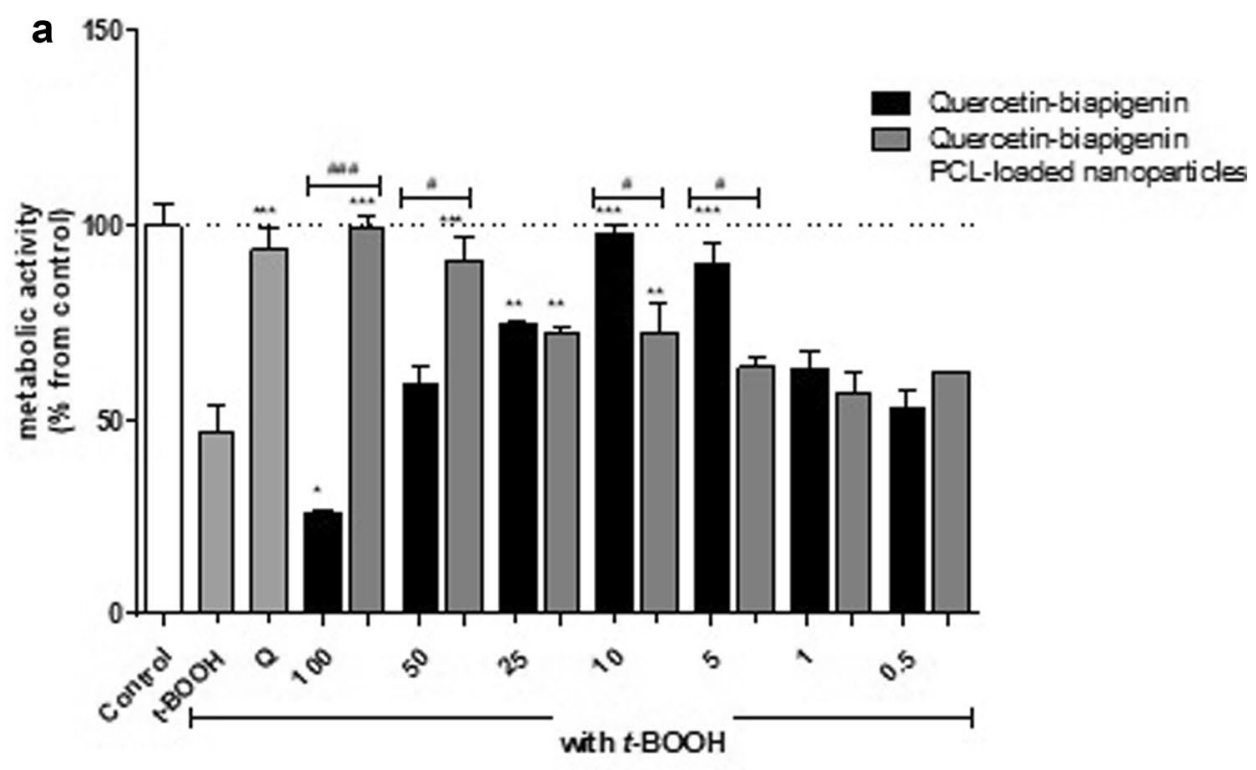

quercetin-biapigen in

concentration $(\mu g / \mathrm{mL})$

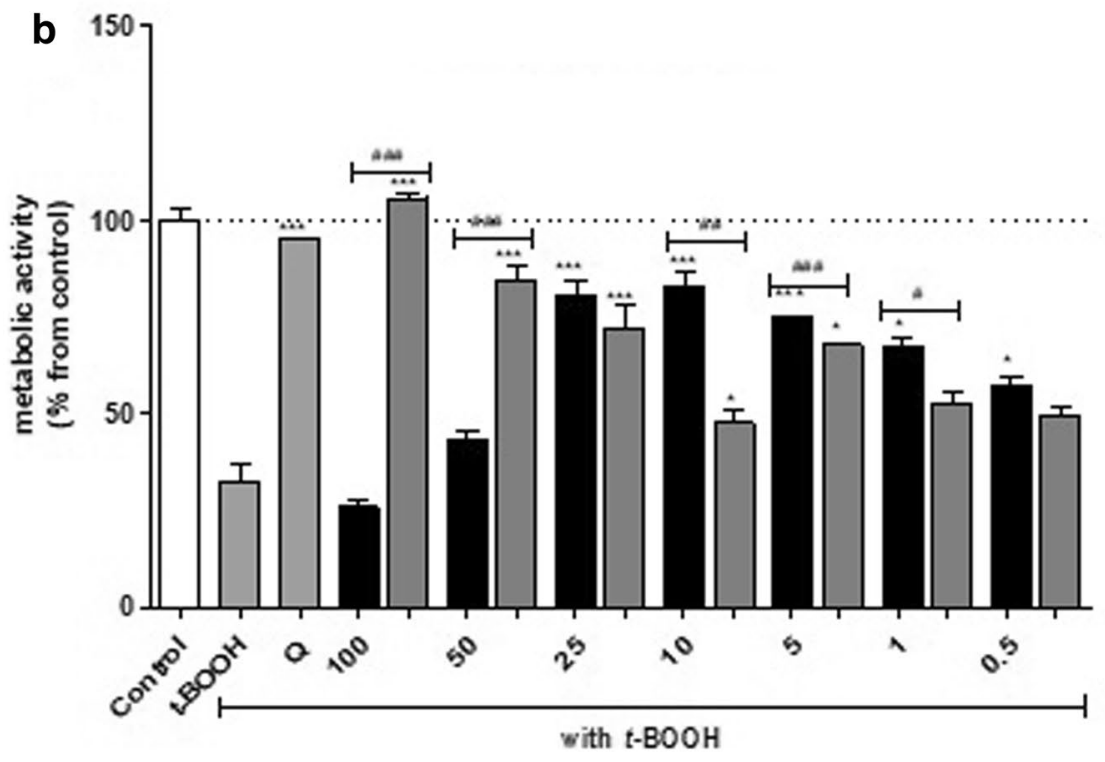

quercetin-biapigenin
concentration $(\mu \mathrm{g} / \mathrm{mL})$

( $p<0.05$, when comparing against $t$-BOOH group), proving that small amounts of these compounds are enough to cause a protective effect over BV-2 cells.

In hcmec/D3 cells and with $3.5 \mathrm{~h}$ of incubation, quercetin-biapigenin in its free form significantly protects from $t$-BOOH-induced toxicity, in concentrations ranging from 1 to $25 \mu \mathrm{g} / \mathrm{ml}$ (Fig. 4a). Quercetin-biapigenin PCLloaded nanoparticles are more protective than pure compounds in the higher concentrations tested $(p<0.05$ for $50 \mu \mathrm{g} / \mathrm{ml}$ and $p<0.001$ for $100 \mu \mathrm{g} / \mathrm{ml}$ ) and can significantly protect against $t$-BOOH induced toxicity, when compared to the $t$ - $\mathrm{BOOH}$ group of cells. When increasing the incubation time for $5 \mathrm{~h}$, there is perceived, generally, a decrease in protection, independently of quercetin and biapigenin encapsulation (Fig. 4b). There was not detected significant protection for quercetin and biapigenin in its free form. Quercetin-biapigenin PCLloaded nanoparticles were more protective than pure compounds in higher concentrations and significantly at $100 \mu \mathrm{g} / \mathrm{ml}(p<0.01)$. 
Fig. 4 Cytoprotection of different concentrations of quercetinbiapigenin in its free form, and in PCL-loaded nanoparticles on homec/D3 cells (3.5 a or 5 b hours co-incubation regimen). Cells were treated with or without compounds along with $0.5 \mathrm{~mm} t$-BOOH for $3.5 \mathrm{~h}$, and cell proliferation was determined by MTT assay. Quercetin $10 \mu \mathrm{m}(\mathrm{Q})$ was used as a positive control. Data is independent experiments. $* p$ $<0.05, * * p<0.01$ and $* * * p^{<}$ 0.001 when compared with the $t$-BOOH control. \#p 0.05 and $\# \# p<0.01$ when comparing two similar concentrations presented as mean \pm SD of three
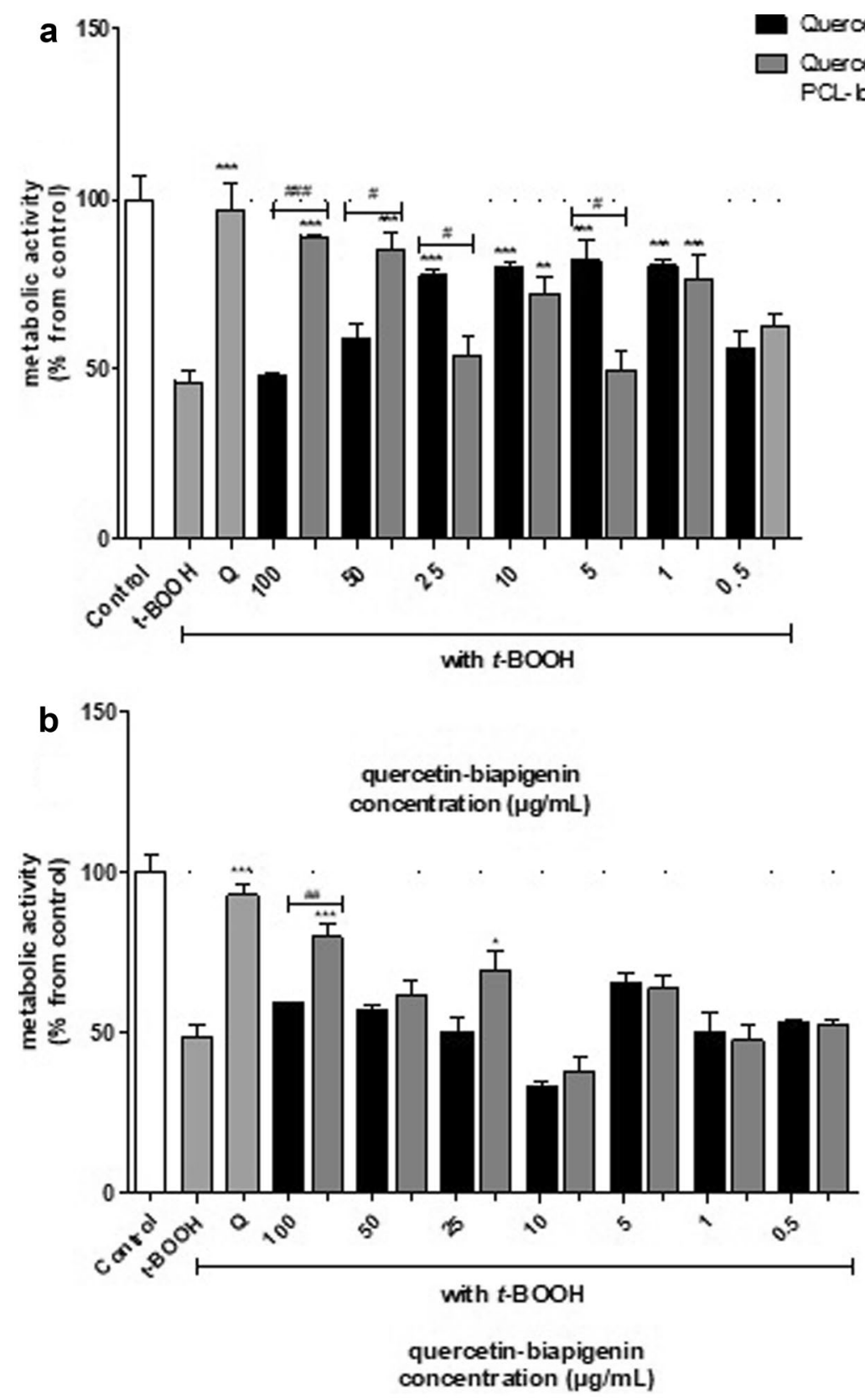

In U87 cells and taking into account also the incubation time of $3.5 \mathrm{~h}$, no significant protection for pure compounds was observed (except $50 \mu \mathrm{g} / \mathrm{ml}$ ) (Fig. 5a). Quercetinbiapigenin PCL-loaded nanoparticles are more protective than pure compounds (in a significant manner at $0.5,1$, 10,25 , and $100 \mu \mathrm{g} / \mathrm{ml}$ ). Nanoparticles were in general significantly more protective against $t$-BOOH induced injury. Contrary to the two previous cells lines described, generally, there was perceived an increase of protection in the second incubation time. Therefore, and with $5 \mathrm{~h}$ of incubation, there was observed a significant protection for pure compounds and quercetin-biapigenin PCL-loaded nanoparticles in the majority of tested concentrations
(Fig. 5b). Pure compounds were significantly more effective than its polymeric nanoparticles, in $100 \mu \mathrm{g} / \mathrm{ml}(p<0.001)$. Quercetin-biapigenin PCL-loaded nanoparticles are significantly more effective than pure compounds in $0.5,10$ $(p<0.001)$, and $25 \mu \mathrm{g} / \mathrm{ml}(p<0.05)$.

\section{Permeability assay}

In the transport study performed, in homec/D3 cells, in order to access quercetin-biapigenin and its PCL-loaded nanoparticles, initial TEER measurements were of $46 \pm 7.8$ $\Omega \mathrm{cm}^{2}$, at the 7 th cell culture day. 
Fig. 5 Cytoprotection of different concentrations of quercetinbiapigenin in its free form, and in PCL-loaded nanoparticles on U87 cells ( 3.5 a or 5 b hours co-incubation regimen). Cells were treated with or without compounds along with $1 \mathrm{~mm}$ $t$ - $\mathrm{BOOH}$ for $3.5 \mathrm{~h}$, and cell proliferation was determined by MTT assay. Quercetin $10 \mu \mathrm{m}$ (Q) was used as a positive control. Data is presented as mean \pm SD of three independent experiments. $* p^{<} 0.05, * * p$ $<0.01$, and $* * * p<0.001$ when compared with the t-BOOH control. $\# p<0.05$ and $\# \# p<0.01$ when comparing two similar concentrations

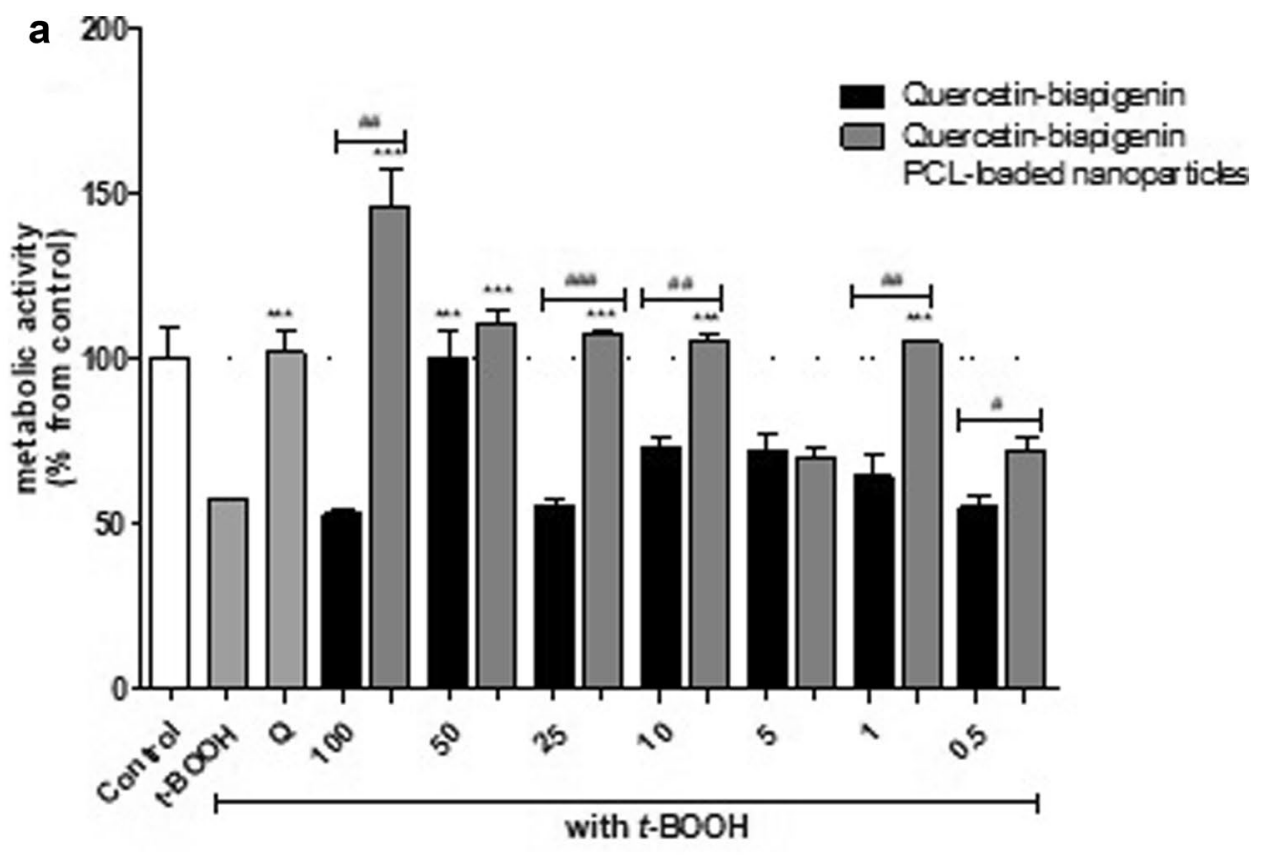

quercetin-biapigen in concentration $(\mu g / \mathrm{mL})$

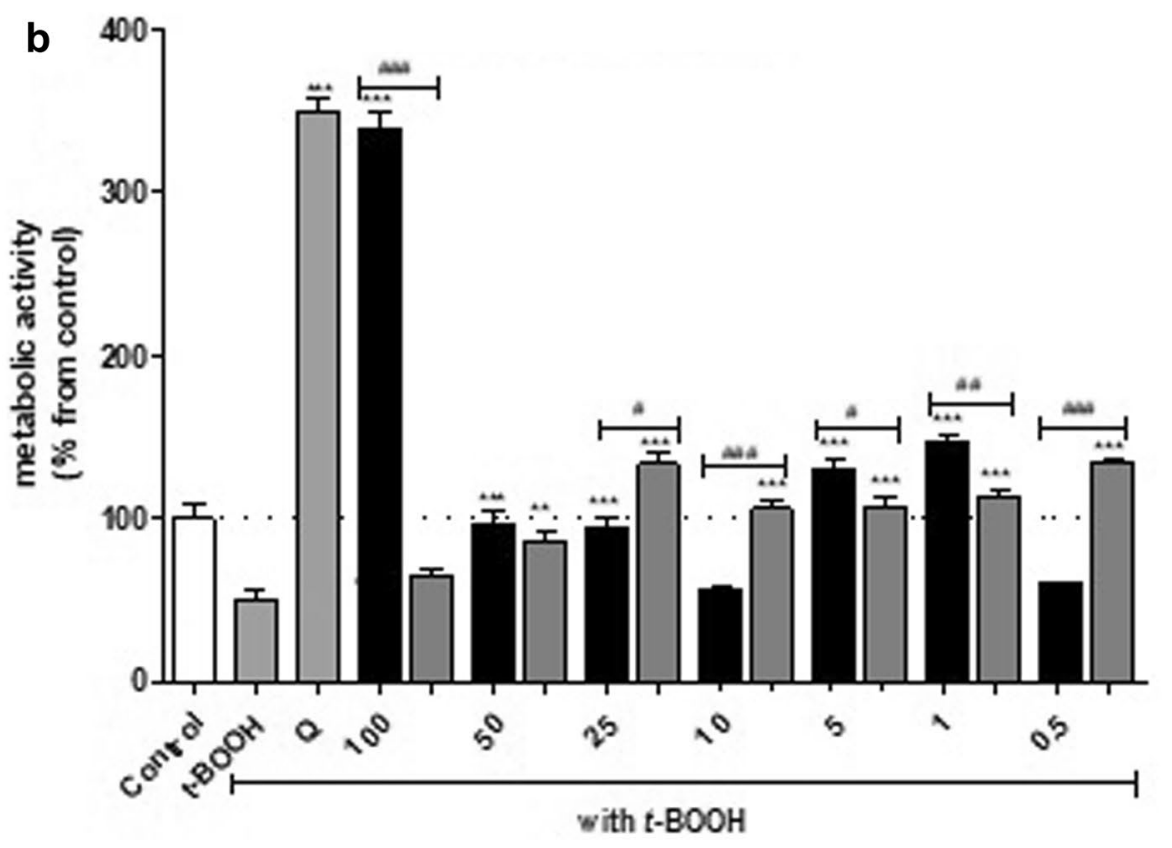

quercetin-biapigen in concentration $(\mu \mathrm{g} / \mathrm{mL})$
During the assay period, 120 min, a slow decrease and steady of TEER was verified, on the Transweel ${ }^{\circledR}$ systems containing quercetin-biapigenin PCL-loaded nanoparticles.
On those containing the compound mixture in its free form, a higher decrease was verified, through the thirstiest minute of the assay (Fig. 6). 
Fig. 6 Cumulative transport and TEER cell measurements of quercetin-biapigenin and its poly( $\mathcal{E}$-caprolactone)-loaded nanoparticles across hcmec/ D3 cells. Data is presented as mean \pm SD of three independent experiments

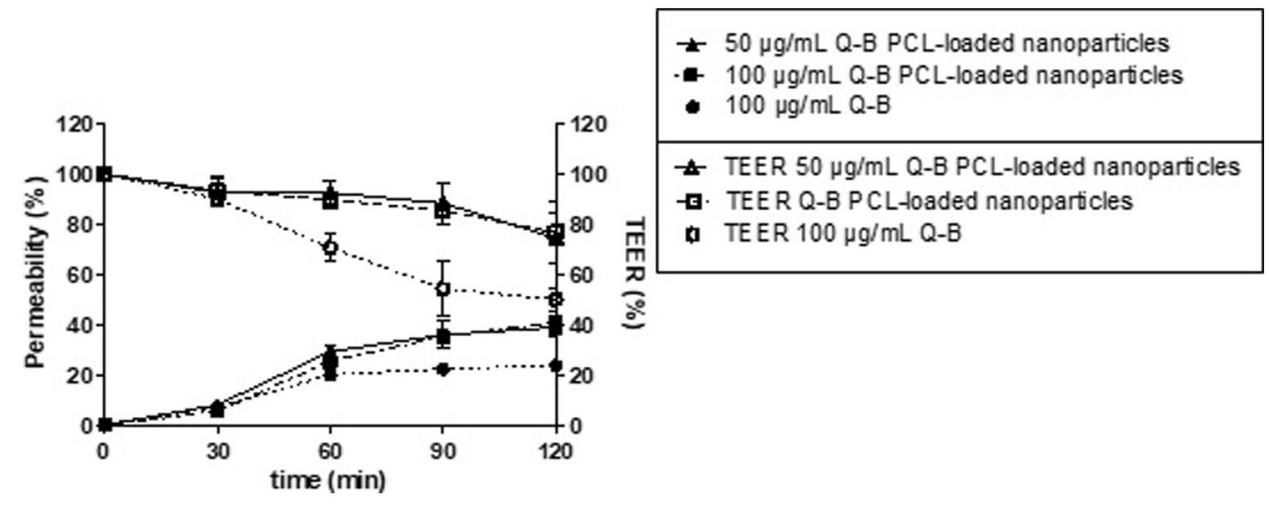

Regarding Papp values, they were of $49.5 \pm 1.46 \times 10^{-6}$ for free quercetin-biapigenin and of $81.2 \pm 8.02 \times 10^{-6} \mathrm{~cm} / \mathrm{s}$ and $85.1 \pm 5.12 \times 10^{-6} \mathrm{~cm} / \mathrm{s}$ for quercetin-biapigenin $(50 \mu \mathrm{g} /$ $\mathrm{ml})$ PCL-loaded nanoparticles and quercetin-biapigenin $(100 \mu \mathrm{g} / \mathrm{ml})$ PCL-loaded nanoparticles, respectively. Papp was calculated only from the apical to basolateral direction.

\section{Discussion}

\section{Neuroprotective assays against tert-butyl hydroperoxide-induced toxicity}

A previous study, from our group, effectively produced quercetin-biapigenin PCL nanoparticles, with a reproductible production method, considering these as good candidates for further studies, including those of CNS activity and BBB permeability [21]. Besides that, and taking into consideration the diversity of cells in the brain that are essential and responsible for a multifunctinal organ response, the study of several cerebral cell lines while investigating a compounds activity in this organ is imperative.

In this study, three cell lines were employed: BV-2, $\mathrm{hcmec} / \mathrm{d} 3$ and U87 cell lines. Microglia are morphologically, antigenically and functionally flexible, having the potential for mobility and proliferation. They are CNS resident macrophage-like cells important in brain's innate immunity and in inflammatory neuropathologies [3]. BV-2 cells, first described by Blasi et al. are a murine cell line, generated through the infection of primary microglial cells with a $v$-raf/ $v$-myc oncogene carrying retrovirus, which resulted in the cell line immortalization. The virus-derived cell line retains most of the immunological properties of active microglia, as secretory and effector cell. It is, therefore, considered a useful in vitro model for studies on the molecular mechanisms that control induction and/or expression of microglia biological functions [32]. Endothelial cells in the CNS microvasculature differ from other vascular endothelia, due to in their capacity in regulating molecules and cells passage to and from the neural parenchyma and constitute the BBB. This selectivity is justified by the unique features of the CNS endothelia, which include the expression of tight intercellular junctions and several receptors, transporters, and nonselective drug export pumps that protect the CNS from a majority of hydrophobic compounds [33, 34]. The homec/D3 cell line, first described by Weksler et al., constitutes the first example of an extensively characterized human brain endothelial cell line, reproducing most of BBB properties. This cell line has been widely used as a human model of brain endothelium in the investigation of the molecular mechanisms of its interaction with CNS and its response to multiple human pathogens known to affect it $[34,35]$. Cancer cell lines, like human glioblastoma U87 cell line, are commonly used as laboratory resources in the study of molecular and cellular biology. This, a long-established cell line derived from a human grade IV glioma, is the most commonly brain cancer cell line studied [36, 37].

The three cell lines under study presented different reactions to $t-\mathrm{BOOH}$. As for $\mathrm{BV}-2$ cell it was, of the three, the one that most reacted to the $t-\mathrm{BOOH}$-induced toxicity. Concentrations higher than $5 \mu \mathrm{g} / \mathrm{ml}$ for both free quercetinbiapigenin and its PCL-loaded nanoparticles were toxic to this cell line. This could be explained by the functions of microglia cells itself. Being the major cellular target of inflammatory mediators in the CNS and taking into account that they can be stimulated during both neuroinflammatory and neurodegenerative disorders [38], it is comprehensible that BV-2 cells are extremely sensitive to compounds that may have a prooxidant activity. As previously described quercetin and possibly biapigenin [39] possess the ability of oxidizing cells. A 24-h exposure to these compounds may have led to cell activation, making the cells with macrophage-like properties and becoming capable of sitedirected phagocytosis. The transformation into and/or recruitment of brain macrophages is, in vivo, accompanied by the release of several secretory products including proteinases, cytokines, reactive oxygen intermediates, and reactive nitrogen intermediates [40]. Activated microglia 
secrete several inflammatory cytokines and cytotoxic agents [41]. Taking in consideration that this study is performed in an in vitro monoculture of cells, this process may have led to the significant loss of cells metabolic activity verified. Quercetin-biapigenin PCL-loaded nanoparticles were able, despite toxic, to have significantly less toxicity than quercetin-biapigenin in its free form, in the higher concentrations tested, reinforcing the importance of formulating nanoparticles capable of protecting the cells from toxic events.

As to our knowledge, there are no studies of quercetin or biapigenin actions on hcmec/D3, regarding those compounds influence on the cell metabolic activity. Reports focus essentially on the influence of compounds on the permeability of this cell line. Quercetin however has been described to activate the transport activity of intestinal P-glycoprotein in clinical relevant concentrations, being possibly able to interfere with BBB P-glycoprotein [42]. In other endothelial brain cell line, MBEC4, quercetin had a biphasic concentration-dependent activity effect on vincristine transports across BBB [43]. Taking this in consideration there cannot be excluded a possible influence of compounds such as quercetin and biapigenin on the metabolic activity of hcmec/D3 cells, as verified in this study, where no toxicity was verified, but where quercetinbiapigenin PCL-loaded nanoparticles, were significantly more protective than pure compounds in concentrations ranging from 5 to $50 \mu \mathrm{g} / \mathrm{ml}$.

For U87 cells, there was no cytotoxicity in the 24-h treatment, for quercetin-biapigenin and its PCL-loaded nanoparticles (except for quercetin-biapigenin PCL-loaded nanoparticles in a concentration of $100 \mu \mathrm{g} / \mathrm{ml}$ ) which in accordance to previous reports for quercetin [44].

In general, quercetin-biapigenin PCL-loaded nanoparticles were able to minimize toxicity of the compounds they convey. This was successfully achieved in our study. In the smaller concentrations and in the three cell lines here in study, quercetin -biapigenin PCL-loaded nanoparticles were less protective than compounds in its free form. This could be explained by a better compound activity in comparison to PCL-loaded nanoparticles, with a possible interference of particle size and surface properties, namely charge, on the cellular uptake efficiency. Negative charge of quercetin-biapigenin PCL-loaded nanoparticles also has influenced the metabolic activity of BV-2 cells [45], particularly with a more prolonged exposure to them, as in the 24-h assay.

Oxidant $t-\mathrm{BOOH}$ is considered a model compound capable of inducing oxidative stress in cell systems by producing free radical intermediates [46], which are of extreme relevance in the development of neurodegenerative diseases.
In the two incubation regimens, studied cells' response also differed, depending on the scenario and cell line under investigation.

In BV-2 cell line, and in the pre-incubation regimen, the one of the three in study that was more sensitive to the oxidant activity of $t$ - $\mathrm{BOOH}$, quercetin-biapigenin PCL-loaded nanoparticles are more protective than pure compounds in higher concentrations. Quercetin-biapigenin was significantly more protective at lower concentrations, similarly to what happened at the 24-h treatment. There are no reports, as to our knowledge, of quercetin and/or biapigenin activity protection of BV-2 against $t$-BOOH. However, pretreatment of BV-2 cells with quercetin has been found to suppress lipopolysaccharide-induced inos expression and $\mathrm{NO}$ generation via regulation of the NF-кb and the Nrf2/HO-1 pathways, indicating that quercetin could suppress abnormal nitrosative stress-induced neuroinflammation in the brain [47].

The findings, in hcmec/D3 cells, for the $24 \mathrm{~h}$ treatment with the compounds that suggested some kind of activity of quercetin-biapigenin over the cells, are reinforced with the ones of the pre-incubation regimen.

For U87 cell line pretreatment with quercetin-biapigenin, generally and independently of encapsulation, did not protect against $t$-BOOH-induced toxicity, which is in apparent accordance to other reports [48, 49]. These studies emphasize, however, the anticancer activity of quercetin, which is not under investigation on the present study. For that reason a complete correlation between the studies is difficult to be performed. Exception made to quercetinbiapigenin PCL-loaded nanoparticles, in compounds concentrations between 1 and $10 \mu \mathrm{g} / \mathrm{ml}$, where protection was verified.

There are, as to our knowledge, no reports of co-incubation studies with these cells lines. Noted that, and as for the co-incubation regimen and in BV-2, the same tendency is perceived in the two selected incubation times. It is again perceived that quercetin-biapigenin PCL-loaded nanoparticles are more protective than pure compounds in higher concentrations. In the intermediate concentrations, the opposite is verified, suggesting a protective activity of the nanoparticles towards toxicity (where, we can also include intrinsic compound toxicity), but a better availability of free compounds in lower concentrations, leading to a more effective activation of intrinsic antioxidant mediators in BV-2 cells, by quercetin and biapigenin.

In hcmec/D3, the same overall tendency is observed, with a however, decrease in protection in the second incubation period studied, $5 \mathrm{~h}$. This could be due to an inefficient protection by quercetin-biapigenin. With an increase in the assay time, $t$-BOOH uptake would increase even more, leading to more deficient protection. 
Last, in U87 cells and taking also into account the incubation time of $3.5 \mathrm{~h}$, in general, quercetin-biapigenin PCL-loaded nanoparticles are significantly more protective against $t$-BOOH-induced injury than the free compounds. Contrary to the two previous cells lines described there was perceived an increase of protection in the second incubation time $(5 \mathrm{~h})$. These results could be explained by a better protection of quercetin-biapigenin nanoparticles against compounds intrinsic toxicity. U87 cells, being a cancer line, possessed an increase resistance to cytotoxic death [50], which could help to explain our results.

Overall, antioxidant properties of the compounds in study can possibly, but not exclusively [51], explain its protective activities against $t$-BOOH-induced injury in the cell lines investigated.

\section{Permeability assay}

The permeability assay performed had the aim of study the ability of quercetin-biapigenin PCL-loaded nanoparticles to effectively cross the BBB, using an in vitro model. Here, and before the transport assay itself, it was necessary to create conditions that could mimic BBB. For that, a static cell monoculture of hcmec/D3 cells was produced. Cells were, therefore, seeded in Transwell@ systems. TEER, a quantitative measurement of the resistance over the cell layer and the cell culture membrane [52], was periodically performed. As the cell monolayer on the apical side of the Transwell ${ }^{\circledR}$ becomes confluent, TEER values increase, quantifying, therefore, "tightness" of the monolayer and in turn cell health by evaluating the resistance to ions across the BBB [53]. In vivo it is accepted that mammalian system shows high TEER values, above $1000 \Omega \mathrm{cm}^{2}$ [35, 54]. However, and under static culture conditions, such as the ones of this study, hcmec/D3 monolayers develop only a low to medium TEER level around 30-50 $\Omega \mathrm{cm}^{2}$ [35]. Despite different experimental conditions in our study, namely culture medium in which the cells were maintained, 7 days after seeding, TEER was measured, obtaining a value of $46 \pm 7.8 \Omega \mathrm{cm}^{2}$, which is in accordance with other studies $[25,35]$. Several factors affect the resistance, such as cell origin and the level of confluence of the cells [52]. Taking into consideration that the absolute value of TEER is believed to be mainly dependent on the amount and complexity of tight junctions between the cells [54] and also in accordance with previous work from the research group, regarding BBB the permeability conditions $[25,55]$, it can be concluded that the in vitro model, regarding this feature, was able to be employed in the permeability assay.

Regarding Papp, it is established that it provides information of a drug permeability characteristics independent of experimental design, due to the fact that it is corrected for the transport surface area, time of the experiment, and applied concentration. It represents, therefore, a value, specific to the drug that provides a prediction for the in vivo Papp. It has no relation with the basal permeability status of the in vitro BBB model. Papp is also considered an excellent drug comparison permeability parameter between experiments [56].

In this study, it was observed that the in vitro model employed was significantly more permeable to the encapsulated quercetin-biapigenin $(p<0.01$ between quercetin-biapigenin and its PCL-loaded nanoparticles with a corresponding concentration of free compounds of $50 \mu \mathrm{g} / \mathrm{ml}$ and $p<0.001$ between quercetin-biapigenin and its PCL-loaded nanoparticles with a corresponding concentration of free compounds of $100 \mu \mathrm{g} / \mathrm{ml}$ ) than to the compounds in its free form. Encapsulated quercetinbiapigenin did not differ its permeation through the BBB model. The studied nanoparticles possess Papp values of $81.2 \pm 8.02 \times 10^{-6} \mathrm{~cm} / \mathrm{s}$ and $85.1 \pm 5.12 \times 10^{-6} \mathrm{~cm} / \mathrm{s}$ and the free compounds of $49.5 \pm 1.46 \times 10^{-6} \mathrm{~cm} / \mathrm{s}$, in close range of some non-CNS drugs, such as famciclovir and trimethoprim for nanoparticles, and labetalol for free compounds [57]. Faria et al. recently reported quercetin's permeation through an in vitro BBB model [58]. However, their results cannot be compared to this study, due to the fact that the authors do not present $\mathrm{Papp}$ values, taking in consideration that the experimental conditions were not similar.

\section{Conclusion}

In this study, the protective activity of quercetin-biapigenin and its PCL-loaded nanoparticles was studied, in three different brain cell lines: $\mathrm{Bv}-2$ microglia, hcmec/D3 endothelial, and U87 glioblastoma cells. Results obtained were diverse, depending on the cell line and the incubation regimen and/or time selected. Antioxidant properties of the compounds in study can possibly, but not exclusively, explain the protective activity against $t$ - $\mathrm{BOOH}$-induced toxicity.

After screening the potential neuroprotective activity of quercetin-biapigenin and its PCL-loaded nanoparticles (through several cell metabolic activity assays), a transport study through an in vitro BBB model was performed. In this study, the in vitro model used, encapsulated quercetinbiapigenin (Papp of approximately $80 \times 10^{-6} \mathrm{~cm} / \mathrm{s}$ ) revealed to be more permeable than the free compounds.

As of our knowledge, this is the first report of the study of quercetin-biapigenin activity in brain cells and the determination of the permeability of free and encapsulated quercetinbiapigenin as an effective nanocarrier for brain delivery. It is essential, however, to perform more studies, in order to accurately determine the drug-induced changes in the in vitro BBB permeability during the permeability assay, to extrapolate to an in vivo situation and fully understand the mechanism of 
action of these compounds and its polymeric nanoparticles in brain cells.

Author contributions As for different contributions for this manuscript, Ana Isabel Oliveira had intervention in all the practical parts of the study and on the elaboration of the paper. Cláudia Pinho intervened on specific parts of the study (cell line assays) aiding on the elaboration of the paper on those specific parts. Bruno Sarmento and Alberto Dias intervened on the structure and elaboration of the article and review it. All authors have knowledge and approve the final version of the manuscript.

Funding This paper was financed by Portuguese funds through FCT-Fundação para a Ciência e a Tecnologia/Ministério da Ciência, Tecnologia e Ensino Superior in the framework of the project "Institute for Research and Innovation in Health Sciences" UID/ BIM/04293/2019. It was also supported by the "Contrato-Programa" UIDB/04050/2020 funded by national funds through the FCT I.P. Ana Isabel Oliveira was supported by Escola Superior de Saúde do Porto and Instituto Politécnico do Porto (Programa de Formação Avançada de Docentes).

Data Availability Data can be obtained from the authors upon request.

\section{Declarations}

Conflict of interest The authors declare that they have no conflict of interest.

\section{References}

1. Floyd RA, Hensley K. Oxidative stress in brain aging. Implications for therapeutics of neurodegenerative diseases. Neurobiol Aging. 2002;23(5):795-807.

2. Pang Z, Lu W, Gao H, Hu K, Chen J, Zhang C, Gao X, Jiang X, Zhu C. Preparation and brain delivery property of biodegradable polymersomes conjugated with OX26. J Control Release. 2008. https://doi.org/10.1016/j.jconrel.2008.03.007.

3. Emerit J, Edeas M, Bricaire F. Neurodegenerative diseases and oxidative stress. Biomed Pharmacother. 2004;58(1):39-46.

4. Gilgun-Sherki Y, Melamed E, Offen D. Oxidative stress inducedneurodegenerative diseases: the need for antioxidants that penetrate the blood brain barrier. Neuropharmacology. 2001;40(8):959-75.

5. Pietta PG. Flavonoids as antioxidants. J Nat Prod. 2000. https://doi. org/10.1021/np9904509.

6. Silva BA, Ferreres F, Malva JO, Dias ACP. Phytochemical and antioxidant characterization of Hypericum perforatum alcoholic extracts. Food Chem. 2005;90:157-67.

7. Silva BA, Malva JO, Dias ACP. St John's Wort (Hypericum perforatum) extracts and isolated phenolic compounds are effective antioxidants in several in vitro models of oxidative stress. Food Chem. 2008;110:611-9.

8. Barbu E, Molnar E, Tsibouklis J, Gorecki DC. The potential for nanoparticle-based drug delivery to the brain: overcoming the blood-brain barrier. Expert Opin Drug Deliv. 2009. https://doi. org/10.1517/17425240902939143.

9. Alam MI, Beg S, Samad A, Baboota S, Kohli K, Ali J, Akbar M. Strategy for effective brain drug delivery. Eur J Pharm Sci. 2010. https://doi.org/10.1016/j.ejps.2010.05.003.
10. Wohlfart S, Gelperina S, Kreuter J. Transport of drugs across the blood-brain barrier by nanoparticles. J Control Release. 2012. https:// doi.org/10.1016/j.jconrel.2011.08.017.

11. Yang H. Nanoparticle-mediated brain-specific drug delivery, imaging, and diagnosis. Pharm Res. 2010. https://doi.org/10.1007/ s11095-010-0141-7.

12. Blasi E, Barluzzi R, Bocchini V, Mazzolla R, Bistoni F. Immortalization of murine microglial cells by a $\mathrm{v}-\mathrm{raf} / \mathrm{v}-\mathrm{myc}$ carrying retrovirus. J Neuroimmunol. 1990;27(2-3):229-37.

13. Dok-Go H, Lee KH, Kim HJ, Lee EH, Lee J, Song YS, Lee Y, Jin C, Lee YS, Cho J. Neuroprotective effects of antioxidative flavonoids, quercetin, (+)-dihydroquercetin and quercetin 3-methyl ether, isolated from Opuntia ficus-indica var. Saboten Brain Res. 2003;965(1-2):130-6.

14. Arredondo F, Echeverry C, Abin-Carriquiry JA, Blasina F, Antunez K, Jones DP, Go YM, Liang YL, Dajas F. After cellular internalization, quercetin causes Nrf2 nuclear translocation, increases glutathione levels, and prevents neuronal death against an oxidative insult. Free Radic Biol Med. 2010. https://doi. org/10.1016/j.freeradbiomed.2010.05.020.

15. Suematsu N, Hosoda M, Fujimori K. Protective effects of quercetin against hydrogen peroxide-induced apoptosis in human neuronal $\mathrm{SH}-$ SY5Y cells. Neurosci Lett. 2011. https://doi.org/10.1016/j.neulet. 2011.09.028.

16. Sasaki N, Toda T, Kaneko T, Baba N, Matsuo M. Protective effects of flavonoids on the cytotoxicity of linoleic acid hydroperoxide toward rat pheochromocytoma PC12 cells. Chem Biol Interact. 2003;145(1):101-16.

17. Silva JP, Gomes AC, Coutinho OP. Oxidative DNA damage protection and repair by polyphenolic compounds in PC12 cells. Eur J Pharmacol. 2008. https://doi.org/10.1016/j.ejphar.2008.10.046.

18. Ansari MA, Abdul HM, Joshi G, Opii WO, Butterfield DA. Protective effect of quercetin in primary neurons against Abeta(1-42): relevance to Alzheimer's disease. J Nutr Biochem. 2009. https://doi. org/10.1016/j.jnutbio.2008.03.002.

19. Silva B, Oliveira PJ, Dias A, Malva JO. Quercetin, kaempferol and biapigenin from Hypericum perforatum are neuroprotective against excitotoxic insults. Neurotox Res. 2008;13(3-4):265-79.

20. Silva BA, Oliveira PJ, Cristovao A, Dias AC, Malva JO. Biapigenin modulates the activity of the adenine nucleotide translocator in isolated rat brain mitochondria. Neurotox Res. 2010. https://doi. org/10.1007/s12640-009-9082-5.

21. Oliveira AI, Pinho C, Fonte P, Sarmento B, Dias ACP. Development, characterization, antioxidant and hepatoprotective properties of poly ( $\varepsilon$-caprolactone) nanoparticles loaded with a neuroprotective fraction of Hypericum perforatum. Int J Biol Macromol. 2018. https://doi.org/10.1016/j.ijbiomac.2017.10.103.

22. Dias ACP, Seabra RM, Andrade PB, Fernandes-Ferreira M. The development and evaluation of an HPLC-DAD method for the analysis of the phenolic fractions from in vivo and in vitro biomass of Hypericum species. Journal of Liquid Chromatoghrafy \& Related Technology. 1999;22(2):215-27.

23. Lima CF, Valentao PC, Andrade PB, Seabra RM, FernandesFerreira M, Pereira-Wilson C. Water and methanolic extracts of Salvia officinalis protect hepg2 cells from t-BHP induced oxidative damage. Chem Biol Interact. 2007. https://doi.org/10.1016/j. cbi.2007.01.020.

24. Carvalho AC, Gregory F, Dias ACP, Lima CF. Methanolic extract of Hypericum perforatum cells elicited with Agrobacterium tumefaciens provides protection against oxidative stress induced in human hepg2 cells. Ind Crops Prod. 2014;59:177-83.

25. Mendes B, Marques C, Carvalho I, Costa P, Martins S, Ferreira D, Sarmento B. Influence of glioma cells on a new co-culture in vitro blood-brain barrier model for characterization and validation of permeability. Int J Pharm. 2015. https://doi.org/10.1016/j.ijpharm. 2015.05.027. 
26. Mohanraj VJ, Chen YN. Nanoparticles - a review. Trop J Pharm Res. 2006. https://doi.org/10.4314/tjpr.v5i1.14634.

27. Fessi H, Puisieux J, Devissaguet JPH, Ammoury N, Benita $\mathrm{S}$. Nanocapsule formation by interfacial polymer deposition following solvent displacement. Int J Pharm. 1989. https://doi. org/10.1016/0378-5173(89)90281-0.

28. Vauthier C, Bouchemal K. Methods for the preparation and manufacture of polymeric nanoparticles. Pharm Res. 2009. https:// doi.org/10.1007/s11095-008-9800-3.

29. Kumari A, Yadav SK, Yadav SC. Biodegradable polymeric nanoparticles based drug delivery systems. Colloids Surf B Biointerfaces. 2010. https://doi.org/10.1016/j.colsurfb.2009.09.001.

30. Hu Y, Jiang X, Ding Y, Zhang L, Yang C, Zhang J, Chen J, Yang Y. Preparation and drug release behaviors of nimodipine-loaded poly(caprolactone)-poly(ethylene oxide)-polylactide amphiphilic copolymer nanoparticles. Biomaterials. 2003. https://doi. org/10.1016/S0142-9612(03)00021-8.

31. Wilkening S, Stahl F, Bader A. Comparison of primary human hepatocytes and hepatoma cell line Hepg2 with regard to their biotransformation properties. Drug Metab Dispos. 2003. https:// doi.org/10.1124/dmd.31.8.1035.

32. Blasi P, Giovagnoli S, Schoubben A, Ricci M, Rossi C. Solid lipid nanoparticles for targeted brain drug delivery. Adv Drug Deliv Rev. 2007. https://doi.org/10.1016/j.addr.2007.04.01.

33. Wolburg H, Lippoldt A. Tight junctions of the blood-brain barrier: development, composition and regulation. Vascul Pharmacol. 2002;38(6):323-37.

34. Weksler BB, Subileau EA, Perriere N, Charneau P, Holloway K, Leveque M, Tricoire-Leignel H, Nicotra A, Bourdoulous S, Turowski P, Male DK, Roux F, Greenwood J, Romero IA, Couraud PO. Blood-brain barrier-specific properties of a human adult brain endothelial cell line. FASEB J. 2005. https://doi.org/10.1096/fj.043458fje.

35. Weksler B, Romero IA, Couraud PO. The hcmec/D3 cell line as a model of the human blood brain barrier. Fluids Barriers CNS. 2013. https://doi.org/10.1186/2045-8118-10-16.

36. Yu SC, Ping YF, Yi L, Zhou ZH, Chen JH, Yao XH, Gao L, Wang $\mathrm{JM}$, Bian XW. Isolation and characterization of cancer stem cells from a human glioblastoma cell line U87. Cancer Lett. 2008. https:// doi.org/10.1016/j.canlet.2008.02.010.

37. Clark MJ, Homer N, O'Connor BD, Chen Z, Eskin A, Lee H, Merriman B, Nelson SF. U87MG decoded: the genomic sequence of a cytogenetically aberrant human cancer cell line. Plos Genet. 2010. https://doi.org/10.1371/journal.pgen.1000832.

38. Kim SS, Lim J, Bang Y, Gal J, Lee SU, Cho YC, Yoon G, Kang BY, Cheon SH, Choi HJ. Licochalcone E activates Nrf2/antioxidant response element signaling pathway in both neuronal and microglial cells: therapeutic relevance to neurodegenerative disease. J Nutr Biochem. 2012. https://doi.org/10.1016/j.jnutbio.2011.07.012.

39. Prochazkova D, Bousova I, Wilhelmova N. Antioxidant and prooxidant properties of flavonoids. Fitoterapia. 2011. https://doi. org/10.1016/j.fitote.2011.01.018.

40. Banati RB, Gehrmann J, Schubert P, Kreutzberg GW. Cytotoxicity of microglia. Glia. 1993. https://doi.org/10.1002/glia.440070117.

41. Nelson PT, Soma LA, Lavi E. Microglia in diseases of the central nervous system. Ann Med. 2002;34(7-8):491-500.

42. Weber CC, Kressmann S, Fricker G, Muller WE. Modulation of P-glycoprotein function by St John's wort extract and its major constituents. Pharmacopsychiatry. 2004. https://doi. org/10.1055/s-2004-832686.

43. Mitsunaga Y, Takanaga H, Matsuo H, Naito M, Tsuruo T, Ohtani $\mathrm{H}$, Sawada Y. Effect of bioflavonoids on vincristine transport across blood-brain barrier. Eur J Pharmacol. 2000;395(3):193-201.
44. Siegelin MD, Reuss DE, Habel A, Rami A, von Deimling A. Quercetin promotes degradation of survivin and thereby enhances death-receptor-mediated apoptosis in glioma cells. Neuro Oncol. 2009. https://doi.org/10.1215/15228517-2008-085.

45. Long TC, Saleh N, Tilton RD, Lowry GV, Veronesi B. Titanium dioxide (P25) produces reactive oxygen species in immortalized brain microglia (BV2): implications for nanoparticle neurotoxicity. Environ Sci Technol. 2006;40(14):4346-52.

46. Sohn JH, Han KL, Lee SH, Hwang JK. Protective effects of panduratin A against oxidative damage of tert-butylhydroperoxide in human hepg2 cells. Biol Pharm Bull. 2005;28(6):1083-6.

47. Kang CH, Choi YH, Moon SK, Kim WJ, Kim GY. Quercetin inhibits lipopolysaccharide-induced nitric oxide production in BV2 microglial cells by suppressing the NF-kappab pathway and activating the Nrf2-dependent HO-1 pathway. Int Immunopharmacol. 2013. https://doi.org/10.1016/j.intimp. 2013.09.009.

48. Zamin LL, Filippi-Chiela EC, Dillenburg-Pilla P, Horn F, Salbego C, Lenz G. Resveratrol and quercetin cooperate to induce senescence-like growth arrest in C6 rat glioma cells. Cancer Sci. 2009. https://doi.org/10.1111/j.1349-7006.2009.01215.x.

49. Sang DP, Li RJ, Lan Q. Quercetin sensitizes human glioblastoma cells to temozolomide in vitro via inhibition of Hsp27. Acta Pharmacol Sin. 2014. https://doi.org/10.1038/aps.2014.22.

50. Xia S, Rosen EM, Laterra J. Sensitization of glioma cells to Fasdependent apoptosis by chemotherapy-induced oxidative stress. Cancer Res. 2005;65(12):5248-55.

51. Kraus B, Wolff H, Heilmann J, Elstner EF. Influence of Hypericum perforatum extract and its single compounds on amyloid-beta mediated toxicity in microglial cells. Life Sci. 2007. https://doi. org/10.1016/j.lfs.2007.07.020.

52. Wolff A, Antfolk M, Brodin B, Tenje M. In Vitro Blood-Brain Barrier Models-An Overview of Established Models and New Microfluidic Approaches. J Pharm Sci. 2015. https://doi. org/10.1002/jps.24329.

53. Hatherell K, Couraud PO, Romero IA, Weksler B, Pilkington GJ. Development of a three-dimensional, all-human in vitro model of the blood-brain barrier using mono-, co-, and tri-cultivation Transwell models. J Neurosci Methods. 2011;199(2):223-9.

54. Madara JL. Regulation of the movement of solutes across tight junctions. Annu Rev Physiol. 1998. https://doi.org/10.1146/annurev. physiol.60.1.143.

55. Gomes MJ, Kennedy PJ, Martins S, Sarmento B. Delivery of sirna silencing P-gp in peptide-functionalized nanoparticles causes efflux modulation at the blood-brain barrier. Nanomedicine. 2017. https:// doi.org/10.2217/nnm-2017-0023.

56. Gaillard PJ, de Boer AG. Relationship between permeability status of the blood-brain barrier and in vitro permeability coefficient of a drug. Eur J Pharm Sci. 2000;12(2):95-102.

57. Mahar Doan KM, Humphreys JE, Webster LO, Wring SA, Shampine LJ, Serabjit-Singh CJ, Adkison KK, Polli JW. Passive permeability and P-glycoprotein-mediated efflux differentiate central nervous system (CNS) and non-CNS marketed drugs. J Pharmacol Exp Ther. 2002. https://doi.org/10.1124/jpet.102.039255.

58. Faria A, Meireles M, Fernandes I, Santos-Buelga C, GonzalezManzano S, Duenas M, Freiras V, Mateus N, Calhau C. Flavonoid metabolites transport across a human BBB model. Food Chem. 2014. https://doi.org/10.1016/j.foodchem.2013.10.095.

Publisher's Note Springer Nature remains neutral with regard to jurisdictional claims in published maps and institutional affiliations. 